\title{
Educação e arte popular: experiência estética para análises filosóficas em Richard Shusterman
}

\author{
Vânia \\ OLÁRIA
}

\section{Resumo}

Esse é um projeto de investigação sobre as condições e as práticas sociais efetivas pelas quais as apresentações artísticas do movimento cultural popular Hip Hop são produzidas e consumidas, no currículo para a Educação de Jovens e Adultos, na escola municipal Regina Helou, no ano de 2008. Origina-se de minha experiência pedagógica com as manifestações artísticas, ditas populares, de jovens negros da periferia de Goiânia. O Rap, o Grafite e o Break - respectivamente música, artes visuais e dança - são explorados de forma intertextual. Fundamento minhas reflexões no livro Vivendo a arte: o pensamento pragmatista e a estética, de Richard Shusterman, editado no Brasil em 1998. Nessa obra, o autor desenvolve sentidos progressistas e democráticos para a filosofia estética, estabelecendo um campo conceitual da arte como experiência, com base em John Dewey (1859-1952). Seu objetivo é considerar e defender esteticamente as formas artísticas populares da mídia/cotidiano. Sentindo-me provocada pelo autor, como objetivo principal investigar o poder pedagógico e estético do Hip Hop, de acordo com pressupostos teóricos da tendência pedagógica Histórico Crítica dos Conteúdos. Para isso, pretendo observar os impasses gerados pela contraposição entre formal e o não formal, através da análise do contexto e da visibilidade / invisibilidade de tais práticas artísticas, que não se enquadram no currículo oficial escolar.

Palavras-chave: Educação, hip hop, intertextualidade. 